Article

\title{
Coping With Turbulence: EU Negotiations on the 2030 and 2050 Climate Targets
}

\author{
Marco Siddi \\ European Union Research Programme, Finnish Institute of International Affairs, Finland; E-Mail: marco.siddi@fiia.fi
}

Submitted: 15 March 2021 | Accepted: 10 June 2021 | Published: 30 September 2021

\begin{abstract}
This article analyses European Union (EU) negotiations on the European Climate Law and the 2030 Climate Target Plan in the aftermath of the Covid-19 pandemic. Adopting Ansell and Trondal's (2018) conceptualisation of turbulence, it argues that the pandemic intensified the environmental turbulence within which European policy makers had been operating following Brexit, the rule of law dispute with Poland and Hungary, and the election of Donald Trump as president of the United States. Organisational turbulence within EU institutions also affected the negotiations, particularly due to the reliance of Commission President Ursula von der Leyen on the political support of East-Central European governments that are sceptical of ambitious climate action. Moreover, the Commission, the European Council and the Parliament have taken different positions on the 2030 climate target and on the governance to pursue subsequent targets. Turbulence of scale-reflecting the nature of the EU as a multi-level actor-became relevant too, as the EU found it difficult to agree on its 2030 climate target due to disputes between member states and European institutions. European decision makers responded to turbulence through major policy initiatives, such as the EU Recovery Plan, the Green Deal agenda, and making funds conditional to the respect of the rule of law. They also pursued intra-EU compromises that accommodated different positions-for instance, on the Climate Law. Nonetheless, turbulence continues to pose a formidable challenge to the progress of the EU's climate agenda.
\end{abstract}

\section{Keywords}

2030 climate and energy framework; climate; European Climate Law; European Green Deal; European Union; turbulence

\section{Issue}

This article is part of the issue "Climate Governance and the European Green Deal in Turbulent Times" edited by Claire Dupont (Ghent University, Belgium) and Diarmuid Torney (Dublin City University, Ireland).

(C) 2021 by the author; licensee Cogitatio (Lisbon, Portugal). This article is licensed under a Creative Commons Attribution 4.0 International License (CC BY).

\section{Introduction}

The European Union (EU) has long pursued a climate agenda in international and domestic contexts characterised by turbulence. Turbulence can be defined as "interactions of events or demands that are highly variable, inconsistent, unexpected or unpredictable" (Ansell et al., 2016, p. 3). As Dobbs et al. (2021) have argued, although there is potential for overlap in their occurrence, the concept of turbulence is distinct from crisis or from a single unexpected development. While a crisis is an individual, profoundly disruptive event, such as Brexit or the Covid-19 pandemic, turbulence encompasses the resulting, accumulated and on-going effects of significant events, including crises. In other words, it is the cumulative concatenation of significant incidents and crises that produces turbulence. Such incidents and crises can thus be "sources of turbulence," but they do not constitute turbulence in themselves. Being the result of such complex interactions, turbulence usually complicates decision and policy making by altering substantially and continuously the broader context and by fostering uncertainty.

For instance, the EU acted in a turbulent context for climate policy in the early 2000s, when it endeavoured to secure enough signatories for the Kyoto protocol to enter into force despite the withdrawal of the United States (Parker et al., 2017). In the 2000s, notwithstanding 
domestic and external challenges-most notably, internal reorganisation after two rounds of treaty amendments and the failure of other main polluters to set emission reduction targets-the EU launched the Emissions Trading Scheme, the world's most significant greenhouse gas emissions (GHG) trading scheme (Lindberg, 2019). It also adopted a comprehensive climate legislative package that included targets for emission reductions, renewable energy and energy efficiency, to be achieved by 2020. Despite the 2008-2009 economic and financial crisis, as well as the failure to secure a global agreement on limiting GHG emissions at the 2009 UN climate conference in Copenhagen, the EU continued to pursue its domestic climate targets and drafted new ones for 2030 (Siddi, 2016, p. 135). Moreover, European diplomacy played an important role in the negotiations leading to the Paris Climate Agreement in 2015. The negotiations were conducted against a volatile background of increasing geopolitical competition between major powers and serious domestic crises (i.e., regarding migration, the eurozone) that exacerbated relations between member states and European institutions (von Homeyer et al., 2021).

While complex domestic and international circumstances have long shaped the broader context in which EU climate policy was formulated, recent developments point to an increase in the number and gravity of sources of turbulence. During Donald Trump's presidency, the US withdrew from the Paris Agreement. Trump's outright denial of climate change also provided a template for likeminded leaders of other countries, such as Jair Bolsonaro in Brazil. Various types of climate change sceptics acquired popularity in Europe too (Vihma et al., 2020). Most significantly, Brexit and Poland's and Hungary's breaches of the rule of law were unprecedented sources of intra-EU turbulence, with negative repercussions also for EU climate policy. The Covid-19 pandemic posed a further, extraordinary challenge to the Union's climate agenda, threatening to derail the recently announced European Green Deal (Siddi, 2020).

The occurrence of such serious, concomitant sources of turbulence calls for an analysis of its impact on EU climate policy. Climate governance is a highly relevant field to explore the effects of turbulence because, due to its multilateral framework and links to numerous other policy areas (i.e., agriculture, industry, financial policy), it is particularly susceptible to being affected by the complex ramifications of turbulence. Recent analyses (such as those in Ansell et al., 2016) have deepened the conceptualisation of turbulence and applied it to the investigation of several domestic and international case studies (i.e., public administration, family policy, private military corporations), but not to climate policy. Together with the other contributions to the thematic issue, the article attempts to address this gap. At the same time, the main goal of the article is empirical. Rather than advancing a new conceptualisation of turbulence, it relies on an existing typology in order to investigate current devel- opments in EU climate policy and their links with the broader political context. By doing so, the article also contributes to the growing body of scholarly literature on EU climate and energy governance in times of crisis (see for instance the special issue edited by von Homeyer et al., 2021), most notably through the systematic investigation and process tracing of key components of the European Green Deal and the 2030 and 2050 agendas.

Specifically, the article draws on Ansell and Trondal's (2018) typology of turbulence and applies it to the investigation of three recent and important developments in EU climate policy: the announcement of the European Green Deal, the drafting of the European Climate Law, and the negotiations on the 2030 Climate Target Plan. Arguably, climate policy and the energy transition took centre stage in EU debates in December 2019, when the newly appointed European Commission presided by Ursula von der Leyen presented its plans for a European Green Deal-a comprehensive, long-term roadmap of policies to advance the energy transition in Europe. Despite the onset of the pandemic in March 2020, the Commission declared that the European Green Deal remained a priority (Simon, 2020). Moreover, it drafted a European Climate Law that codifies the 2050 climate neutrality target and proposed a 2030 Climate Target Plan, namely a framework to achieve a more ambitious EU GHG reduction target for 2030 . The three climate policy developments under analysis are closely interrelated but of different nature. While the Green Deal encompasses a broad set of policies and strategies, the Climate Law is a specific legislative initiative and the 2030 Climate Target Plan is a framework that needs to be implemented through the adaptation of policy and legislation. In order to be agreed upon, all of them have required sustained negotiations involving EU institutions and member states. Turbulence produced by international and domestic developments influenced significantly these negotiations.

The article begins with a conceptual discussion of turbulence and of how it relates to EU climate policy. It identifies three main types of turbulence that have influenced EU climate policy. In the subsequent empirical analysis, the article traces the impact of turbulence on the political process that led to the formulation of the European Green Deal (in December 2019) and on the negotiations concerning the European Climate Law and the 2030 target until May 2021, when the European Council and the European Parliament reached a provisional agreement on the Climate Law and the 2030 target. This was a crucial period for EU climate policy, particularly thanks to progress on framing an agenda to pursue the energy transition and achieve major emission reductions. While negotiations on the European Climate Law and the 2030 Climate Target Plan are still ongoing at the time of writing, their development in 2020 and early 2021, in a highly turbulent context, allows for an assessment of how turbulence can influence EU deliberations on climate governance. 


\section{Conceptualising and Tracing Turbulence}

\subsection{Sources of Turbulence and EU Climate Governance}

The term "turbulence" has been used in several disciplines with different meanings. In social sciences, it usually refers to a series of disruptive, highly variable and sometimes unpredictable events. While turbulence and crises can be interrelated, the concept of turbulence is distinct from crisis. A crisis is a single, disruptive event or development, such as Brexit, Covid-19 or the breach of the rule of law in some EU member states. Turbulence is the resulting, cumulative effect of significant crises and incidents (Dobbs et al., 2021), which creates an "increasingly volatile context for complex problem-solving" (Ansell et al., 2020, p. 951) and can pose a challenge to decision making and governance. Hence, crises or individual incidents can be sources of turbulence, but do not constitute turbulence in themselves. Furthermore, not all crises or incidents are sources of turbulence. Some are just aspects of ordinary politics and policy making - for instance, disagreements in parliamentary debates or in negotiations between European institutions-and can be solved in due course, without cumulative effects that pose a challenge to governance.

As argued, turbulence is the effect of several disruptive events and crises. However, as the concept is used to describe their long-term interaction, it also expresses a cumulative state of affairs that can in turn contribute to aggravating individual crises. In other words, turbulence is the effect of crises, but it can also be a cause of their entrenchment and further radicalisation. Moreover, turbulence has an impact on governance. While the impact can vary from case to case and depend on the policy area, turbulence usually poses a sustained, long-term challenge to existing governance mechanisms and calls for a complex response by policy makers. For instance, policy makers need to decide whether they want to govern against turbulence, fixing its symptoms and bypassing it as much as possible, or with turbulence, by acknowledging that it is part of a "new normal" and building flexibility and resilience to respond to it more effectively in the future (Dobbs et al., 2021).

Following Ansell and Trondal (2018), this article focuses on three interrelated dimensions of turbulence that are particularly relevant from a governance perspective: environmental turbulence, organisational turbulence, and turbulence of scale. While this typology of turbulence can have an impact on any aspect of EU governance, the focus here is on examples that are more closely related to EU climate policy. Due to the paramount challenge posed by climate change and the pressure stemming from current European public debates, climate policy has been a central issue of EU governance in recent years. Moreover, because of its multilateral nature and links to numerous other policy areas, climate policy is particularly susceptible to being affected by the complex ramifications of turbulence.
Environmental turbulence has been a defining feature of this period. It concerns contextual, external forms of turbulence, such as Covid-19, Brexit, as well as broad and disruptive policy shifts or upheavals in the European polity. Since March 2020, the Covid-19 pandemic has been a major source of environmental turbulence for European (and global) politics and society. The cumulative effects of Covid-19 in different policy areas (i.e., healthcare, the economy, citizen mobility), in combination with other highly disruptive crises such as Brexit, have posed serious governance challenges to the EU. Most notably, the high human and economic cost of the pandemic has called for prompt and radical policy responses by EU leaders. During the autumn of 2020, the conflict regarding rule of law violations in Poland and Hungary between these two member states, on the one hand, and the European Commission and other member states, on the other, became another important source of environmental turbulence. While the dispute had been going on for years (Gora \& de Wilde, 2020), it reached a climax when the Commission and a majority of member states expressed their wish to tie the disbursement of European recovery funds to the respect of the rule of law. The Polish and Hungarian reaction led to an impasse that delayed the adoption of the entire EU budget, including funds essential for the EU to demonstrate a credible commitment to its 2030 Climate Target Plan.

Throughout 2020, fraught negotiations over Brexit and occasional tensions between the EU and the United States were further sources of environmental turbulence. Following Brexit, the EU lost a member state that supported its climate action domestically and internationally (Bocse, 2020). Within the EU, the United Kingdom was a key proponent of policy solutions in the field of climate policy and supported higher than average emissions reduction targets (despite not being very ambitious with regard to the renewable energy target, see Bocse, 2020, pp. 270-271). In December 2020, Prime Minister Boris Johnson announced that the country will reduce its emissions by 68 percent by 2030 compared to the year 1990, a higher target than that pursued by the EU (Harvey, 2020). The UK also played an important role in EU climate finance, both through its contribution to the EU budget and through the provision of international green finance by UK-based institutions. Moreover, following Brexit, the EU is no longer able to rely on the large resources and networks of the British diplomatic service to support its climate action internationally. While the effects of Brexit for EU climate policy will become clearer in the longer term, and largely depend on the extent of EU-UK cooperation in this policy area (cf. Dupont \& Moore, 2019), the considerations made here highlight that Brexit can be a source of significant turbulence. In the period 2016-2020, the main impact of Brexit on EU climate policy was that Brexit-related negotiations distracted some European resources and attention from the climate agenda (Bocse, 2020). As for relations between the $\mathrm{EU}$ and the United States, uncertainty 
concerning the outcome of the US presidential election of November 2020 implied that the EU had to decide upon its climate targets for 2030 and 2050 without knowing whether its main ally and the world's second largest polluter would re-join multilateral efforts to tackle climate change or (in case of Trump's re-election) continue to undermine them.

Organisational turbulence concerns turbulence within organisations, stemming for instance from administrative reform or internal disagreements that disrupt the ordinary policy or administrative processes. Within the EU, profound disagreements between the European Parliament and the European Council concerning the appointment of a new Commission in 2019, institutional reorganisation following Brexit and inter-institutional conflicts of competence were sources of environmental turbulence. In 2019, the European Council rejected the candidates proposed by the European Parliament for the post of Commission President, which marked an abrupt departure from the Spitzenkandidaten system adopted in 2014 (cf. Heidbreder \& Schade, 2020). Thereafter, the Parliament approved Ursula von der Leyen's nomination with a scant majority of nine votes. Von der Leyen's subsequent focus on the European Green Deal possibly aimed also at broadening her support in the Parliament through a more ambitious agenda that could draw the support of Greens/EFA group members. Despite this, the Parliament maintained a critical stance on some key Commission proposals in the field of climate policy. Thus, significant inter-institutional disagreements continued on central questions such as the targets and governance mechanisms for the 2030 and 2050 climate goals.

Turbulence of scale can occur in multi-level governance structures such as the EU when a decision taken at one level-for example in a member state-has significant consequences at another level-for instance, at the EU level. The rule of law dispute concerning Poland and Hungary and their decision to veto the EU budget had disruptive consequences also for EU-wide climate policy, as it prevented the adoption of the 2030 Climate Target Plan due to the lack of agreement on the funding necessary to pursue it. This also had an impact at the international level. As the EU's 2030 emission reduction target was also its nationally determined contribution in the framework of the Paris climate agreement, the Union had to withhold from announcing it in multilateral contexts until an intra-EU compromise was reached. Hence, the rule of law dispute had a disruptive scalar effect, producing turbulence both inside the EU and at the international level.

It is important to note that different types of turbulence are often interconnected and that a crisis or disruptive incident can be a source of different types of turbulence. For instance, Brexit is primarily a source of environmental turbulence. At the same time, the departure of British representatives also led to an unprecedented reorganisation of EU institutions and thus contributed to organisational turbulence. The rule of law dispute concerning Poland and Hungary was a source of environmental turbulence, as the ensuing confrontation at the EU level had an impact on numerous policy areas (highlighted by the Polish and Hungarian veto on the entire EU budget). However, it also had a scalar effect when the Polish and Hungarian veto on the EU budget prevented EU diplomacy in multilateral arenas where funding is an essential component of EU external action.

\subsection{Process Tracing and Sources}

Process tracing offers an apt methodology to investigate the interaction between turbulence and EU negotiations on the Climate Law and the Climate Target Plan. Collier (2011, p. 824) defines process tracing as "an analytic tool for drawing descriptive and causal inferences from diagnostic pieces of evidence-often understood as part of a temporal sequence of events or phenomena"; it "can contribute decisively both to describing political and social phenomena and to evaluating causal claims" (p. 823). Transposing this reasoning to the subject of this study, process tracing allows drawing descriptive and causal inferences about the relationship between turbulence and EU climate negotiations as they unfolded over time. In order to trace developments and facilitate the identification of causal mechanisms, the empirical analysis follows a chronological approach. This approach also allows zooming into specific instances of policy output (the launch of the Green Deal, the publication of the draft Climate Law and of the 2030 Climate Target Plan) as they occur. While process tracing addresses trajectories of change and causation, describing key events and situations at one point in time is also essential. Hence, it is important to focus on "good snapshots at a series of specific moments" (Collier, 2011, p. 824). For the topic under analysis here, this means focusing on the main instances of policy making and negotiations-such as the Commission's release of key documents, European Council summits, trilogues-by gathering and analysing trustworthy evidence.

Accordingly, official EU policy and legal documents are the main primary sources for this studymost notably, the Commission Communication on the European Green Deal, the European Climate Law, the main Commission communications concerning the 2030 Climate Target Plan, and the EU Recovery Plan. In addition, the daily Bulletin Quotidien Europe (Europe Daily Bulletin) issued by Agence Europe provides the main source repository for tracing the developments and causal relationships in the negotiations on the EU climate agenda during the autumn and winter 2020-2021. Agence Europe is a trustworthy, independent press agency that collects, publishes, and distributes news and in-depth analyses concerning the European Union. The Bulletin Quotidien Europe is its main publication. It is typically based on insider knowledge of ongoing negotiations and policy making in the European institutions. Information drawn from this source repository is critically assessed against and complemented by reference 
to scholarly work and contemporary analyses published in reputable dailies reporting on European politics, such as the Financial Times, and news websites specialised in EU politics, most notably Euractiv.

\section{Turbulence and Negotiations on Climate Targets in the EU}

\subsection{The European Green Deal: A Response to Environmental and Organisational Turbulence?}

EU climate and energy governance is structured around three main headline targets concerning GHG emission reduction from 1990 levels, the share of renewable energy in final energy consumption and improvement in energy efficiency. For the year 2020, the EU-level goal for each of the three headline targets was 20 percent. In 2014, the European Council adopted new goals for 2030: a GHG emissions reduction target of at least 40 percent, and a target of at least 27 percent for both renewable energy and energy efficiency. The targets for renewable energy and energy efficiency were revised following the adoption of new legislation in 2018. The target for renewable energy was increased to at least 32 percent (Directive 2018/2001) and that on energy efficiency to at least 32.5 percent (Directive 2018/2002; for detailed discussion, see Oberthür, 2019). On the other hand, despite some discussions about raising the GHG reduction target in 2015-2018, it remained set at "at least 40 percent" compared to 1990 levels (Directive 2018/410 and Regulation 2018/842).

The appointment of the von der Leyen Commission and its proposal of a European Green Deal in December 2019 provided a framework for a new upward revision of EU climate targets. The Commission Communication on the European Green Deal proposed to "transform the EU into a fair and prosperous society, with a modern, resource-efficient and competitive economy where there are no net emissions of greenhouse gases in 2050" (European Commission, 2019, p. 2). Among its most significant measures, the Communication announced that the Commission would draft a European Climate Law by March 2020, which would "enshrine the 2050 climate neutrality objective in legislation" (European Commission, 2019, p. 4). Furthermore, the Commission stated that it would present "an impact assessed plan to increase the EU's greenhouse gas emission reductions target for 2030 to at least 50 percent and towards 55 percent compared with 1990 levels" by the summer of 2020 (European Commission, 2019, p. 4).

The Green Deal Communication was the first important policy announcement of the newly appointed Commission. This raises the question of why von der Leyen decided to prioritise climate policy and focus on revising climate targets that had been codified in EU legislation only a year earlier. Based on her public statements, environmental turbulence was an important driver of her agenda. In her Political Guidelines for the Next European
Commission 2019-2024, published in July 2019 (while she was still a candidate for the post of Commission President), von der Leyen listed a European Green Deal as the first "headline ambition" and declared that:

The message from Europe's voters-and those too young to vote-is loud and clear: They want real action on climate change and they want Europe to lead the way. I have been inspired by the passion, conviction and energy of the millions of our young people making their voice heard on our streets and in our hearts. They are standing up for their future and it is our generational duty to deliver for them. (Von der Leyen, 2019, p. 5)

Hence, the Green Deal was at least partly a response to one of the main political messages of the European parliamentary elections of April 2019, in which Green parties in large Western member states significantly increased their support by campaigning on a platform that focused on climate action (Mudde, 2019). Most significantly, the Green Deal was inspired by the emergence and surging popularity of youth grassroots movements such as Fridays for Future and Youth Strike for Climate (Knops, 2021). The rise of Fridays for Future and Youth Strike for Climate was an important source of environmental turbulence because they constituted unprecedented, transboundary civil society movements that called for radical governance responses to climate change across numerous policy areas. Moreover, it took place in a context of growing evidence and mediatisation of the climate crisis, which was highlighted by repeated record high summer and winter temperatures, the melting of polar ice and glaciers and catastrophic forest fires in Sweden, Siberia and Australia in 2018-2019.

Arguably, organisational turbulence within the EU also played a role in von der Leyen's prioritisation of the Green Deal. Before the 2019 European election, party groups in the European Parliament proposed their candidates (Spitzenkandidaten) for the post of Commission President, following a practice introduced at the previous European election in 2014 (Heidbreder \& Schade, 2020). However, the European Council refused to endorse the Spitzenkandidaten proposed by the Parliament and backed the candidacy of Ursula von der Leyen. This new inter-institutional conflict left von der Leyen in the difficult position of having to secure the endorsement of a displeased European Parliament. Due to these circumstances and to election results, her backing in the main party groups - the European People's Party, the Progressive Alliance of Socialists and Democrats and Renew Europe-seemed hardly sufficient to guarantee her a majority. Hence, foregrounding the Green Deal in her agenda was functional to her quest of support among members of the Greens/EFA, the fourth largest group. Nonetheless, members the Greens/EFA group voted against her appointment because they considered her commitments insufficient (Greens/EFA, 2019). Their 
opposing vote left von der Leyen with a very small majority in the Parliament. The need to broaden her support base (particularly to the Greens/EFA group) was possibly one of the factors that led her to foreground and further prioritise the Green Deal in the following period.

\subsection{The European Climate Law and the 2030 Climate Target Plan}

In early March 2020, the Commission duly presented a draft European Climate Law, including the climate neutrality objective for the year 2050 (for an analysis of the March draft, see Siddi, 2020, pp. 7, 10). The draft also called upon the Commission to review the Union's GHG emission reduction target for 2030 (set at 40 percent compared to 1990, as of March 2020) and "explore options for a new 2030 target of 50 to 55 percent" (European Commission, 2020a, p. 14). The draft law proposed a governance mechanism to regularly adjust the trajectory toward the 2050 target following the timeline set by the global stocktakes of the Paris Agreement. Most notably, Article 3 would empower the Commission to review the GHG target by delegated acts, namely without having to go through full negotiations with the European Parliament and the member states. This proposal became a source of inter-institutional contention. The Parliament voiced its opposition to the use of delegated acts to review the target already in late March. A non-paper prepared by the Parliament's legal service stated that delegating the power to the Commission to set out the trajectory for achieving climate neutrality by 2050 was not in line with Article 290 of the Treaty on the Functioning of the European Union. According to the non-paper, emission reduction targets are "indisputably elements which are "essential" to the Union policy on fighting climate change" and entail "fundamental political choices" that cannot be delegated to the Commission (European Parliament, 2020, p. 4; cf. Agence Europe, 2020a).

Before the issue of the use of delegated acts reached the European Council-arguably the institution that had the most important say on the matter-the Covid-19 pandemic arrived in Europe. This major source of environmental turbulence led to an immediate refocus of debates and policy initiatives. EU institutions had to cope with criticism for failing to coordinate a prompt, joint response and to procure protective equipment. They also faced self-interested member state policies, such as national export bans on protective equipment, which prevented or hampered joint EU action (Brooks \& Geyer, 2020). As a result, for most of the spring, climate governance debates receded into the background of EU politics. Some government representatives of Eastern European member states argued that the EU should delay or revise its climate agenda in order to focus on the economic consequences of the pandemic (Khan \& Brunsden, 2020). In mid-April 2020, the Commission announced that some of the less urgent policies of the
Green Deal were delayed until 2021, but the schedule for key priorities (such as the assessment of new emission reduction targets for 2030) remained unchanged (Simon, 2020).

The Commission's Communication Europe's Moment: Repair and Prepare for the Next Generation, published on 27 May 2020, clarified that the Green Deal and the climate targets took priority in the EU's plans for the post-pandemic recovery. The Commission announced its intention to borrow 750 billion Euros on the financial markets, thereby supplementing a revamped EU budget of approximately 1,100 billion Euros for the years 2021-2027. It also declared that 25 percent of the EU budget was to be spent on climate investments, a target that was later raised to 30 percent (Dupont et al., 2020, p. 1102). The Communication defined the Green Deal as an essential part of the economic recovery and as "Europe's growth strategy" (European Commission, 2020b, p. 4). In this context, it described the climate neutrality goal by 2050 and ambitious climate targets for 2030 as a crucial framework to provide long-term certainty and predictability for private investments (European Commission, 2020b, p. 6). The Communication was a response to the unprecedented environmental turbulence caused by Covid-19. Therefore, while the pandemic caused a partial delay of the Green Deal agenda, it also elicited a governance response that reiterated and foregrounded climate targets. This was highlighted further in the Communication on the 2030 Climate Target Plan and in the amended proposal for a European Climate Law, both published on 17 September 2020, which raised the 2030 GHG reduction target to "at least 55 percent" compared to 1990 levels (European Commission, 2020c, p. 19; 2020d).

\subsection{The EU Climate Agenda in the Autumn and Winter 2020-2021: Coping With Multiple Sources of Turbulence}

In the autumn of 2020, the Commission was to seek approval of the European Council for the Climate Law and the 2030 Climate Target Plan. However, multiple sources of turbulence accompanied and influenced negotiations on the climate agenda. By early fall, it had become clear that a second wave of Covid-19 infections was in full swing throughout Europe. While EU institutions and member states were now better prepared to cope with Covid-19, the new wave of infections and the uncertainty about the timeline for producing and distributing vaccines aggravated the negative economic and societal effects caused by the pandemic in spring 2020. Nonetheless, while the second wave of the pandemic generated further environmental turbulence, it did not appear to have a direct impact on negotiations on the Climate Law and the 2030 targets in the autumn. The argument that the EU's climate agenda should be delayed or revised due to Covid-19, which had been made by prominent Eastern European politicians the previous spring, no longer held sway. This can be explained 
by the fact that, by the autumn of 2020, the European Commission had formulated a policy response to the pandemic (epitomised by the Communication Europe's Moment) within which climate action remained a priority and was seen as a driver of the economic recovery.

However, new sources of disagreement emerged. In October, member states formally rejected the Commission's proposal to use delegated acts to set the trajectory toward climate neutrality (Agence Europe, 2020b). Moreover, member states disagreed on several issues pertaining to the Climate Law and the 2030 Climate Target Plan. A group of countries including Sweden, Finland, Denmark, Austria, the Netherlands, Luxembourg, Latvia, and Spain would have liked the climate neutrality target to apply to each member state, rather than just at the EU level. Neither this nor their proposal to state that the EU should aim for negative emissions after 2050 was included in the text of the Climate Law. Most Eastern members consistently opposed such ambitious language (Agence Europe, 2020b). Arguably, the relative influence of Eastern members on EU climate policy - a field where they tend to be less ambitious than most other members-increased following Brexit. For EU climate action, Brexit entailed the departure of a large member state with traditionally ambitious emissions reduction targets (Bocse, 2020; Loss, 2020). Thus, besides being a source of environmental turbulence and a distraction from the climate agenda, Brexit tilted the balance in negotiations on emissions reduction in favour of reluctant member states.

Moreover, a group including Bulgaria, Poland, Romania, Slovakia, Hungary, the Czech Republic, and Lithuania (unsuccessfully) argued that the text of the Climate Law should include a reference to the principle of "technological neutrality," allowing member states to determine their energy mix. They also maintained that reference to the "enabling framework" - the set of tools, incentives, and investments to assist member states in the energy transition taking into account their different starting points-should be included in the main body of the law, rather than only in recital 11 (cf. European Commission, 2020a, p. 11). This amendment was not accepted due to firm opposition of a group of Nordic and Western countries, but a sentence requiring the Commission to assess "adequate instruments and incentives for mobilising the investments needed" was included in Article 3(2) of the consolidated draft (Agence Europe, 2020b).

This compromise, together with the postponement of a decision on the 2030 targets (Agence Europe, 2020c), aimed to pave the way for a swifter adoption of the Climate Law and the long-term zero net emission target. Like the EGD's Just Transition Fund-an EU funding mechanism that aims to alleviate the socio-economic impact of the energy transition in regions that rely heavily on the fossil fuel value chain - these measures aimed to assuage the economic concerns of Eastern members (Siddi, 2020, p. 6). This approach seemed to be vindi- cated when, in mid-November 2020, the ambassadors of member states to the EU approved the proposal to start inter-institutional negotiations ("trilogues," including the European Council, the European Parliament and the European Commission) on the text of the Climate Law as redrafted in October (Agence Europe, 2020d).

However, while member states and $\mathrm{EU}$ institutions worked to overcome their disagreements, climate negotiations were affected by two major interrelated sources of environmental turbulence: the dispute on Polish and Hungarian violations of the rule of law and the difficult negotiations on the EU's Multiannual Financial Framework (MFF) for 2021-2027. For over two years, Poland and Hungary had been facing a procedure under article 7 of the Treaty on European Union for serious violations of the rule law (Gora \& de Wilde, 2020). Although EU institutions and other member states repeatedly called on Poland and Hungary to redress rule of law violations, the issue remained unsolved (European Parliament, 2020) and became intertwined with the complex negotiations on the MFF. In early November 2020, trilogue negotiations on the MFF reached a political agreement on a mechanism that tied both the Just Transition and the MFF funds to the respect of the rule of law (Makszimov, 2020).

The prospect of losing access to part of their EU funds led Poland and Hungary to veto the EU's 2021-2027 budget and the post-pandemic recovery programme, both of which included the funding necessary to pursue the Green Deal and the EU's climate objectives (Gera, 2020). The Polish and Hungarian veto was also a source of turbulence of scale, as it prevented the adoption of the EU's nationally determined contribution to the Paris climate agreement for 2030. A decision taken at member state level had consequences for climate policy at both the European level (by stalling intra-EU negotiations) and at the international level (by delaying the announcement of a crucial EU target within the multilateral framework of the Paris Agreement). Eventually, a compromise between Poland and Hungary and other EU member states was reached at the European Council summit of 10-11 December 2020. The mechanism allowing the suspension of EU funds in case of rule of law violations remained in place, but the Commission agreed not to launch a sanction procedure against any member states until the European Court of Justice (ECJ) decides on the legality of the mechanism (Valero, 2020).

While the conflict may resurface following the ECJ's decision, potentially generating further turbulence, the compromise reached in December 2020 allowed the EU to adopt a 1.8 trillion budget including climate finance (European Council, 2020, pp. 1-4). This paved the way for the European Council's adoption of the Climate Target Plan with a revised GHG reduction target of "at least 55 percent" compared to 1990 (European Council, 2020, p. 5). Subsequently, on 18 December, the Commission forwarded the new target to the United Nations Framework Convention on Climate Change, as 
required by the Paris Agreement. Nonetheless, details on how to achieve the target remained to be agreed. A group of Eastern European member states consider future financial support essential to pursue the target (Agence Europe, 2020e, pp. 1-2). Furthermore, interinstitutional disagreements returned to the fore due to the more ambitious stance of the European Parliament on the 2030 target. This emerged with particular clarity at the third round of trilogue negotiations in early February 2021. The Parliament proposed to raise the 2030 target to 60 percent and to make the 2050 climate neutrality goal applicable to all member states, rather than just to the EU as a whole. However, the Council declined both proposals and the negotiations were reportedly stalled (Agence Europe, 2021). The Council and the Parliament reached a provisional agreement only after several months of intense negotiations, in early May 2021. The main terms of the agreementa reduction target of at least 55 percent for 2030, climate neutrality "within the Union" by 2050-reflected the Council's position (European Council, 2021, p. 28).

\section{Conclusion}

This article made an empirical contribution to the incipient corpus of scholarly literature on recent, crucial developments in the EU's climate agenda, most notably the European Green Deal and the 2030 and 2050 climate frameworks. While its main contribution was empirical, the article also engaged with the scholarly debate on the concept of turbulence. It relied on Ansell and Trondal's (2018) typology of turbulence to investigate EU climate action. Previously, this typology had not been applied specifically to a case study on climate policy. However, as the article attempted to demonstrate, climate action is a highly relevant field for this investigation because it is particularly exposed to the complex ramifications of turbulence. The analysis revealed that environmental turbulence was an essential feature of the period under consideration and had an important impact on the EU climate agenda. The announcement of the European Green Deal in December 2019 was partly a response to the outcome of the 2019 European elections and, most notably, to the environmental turbulence generated by an unprecedented wave of transnational youth protest movements demanding climate action. The drafting of the European Climate Law in March 2020, including the 2050 climate neutrality goal, can also be seen as a governance response to young demonstrators' demands of a long-term strategy to tackle climate change.

During 2020, new sources of environmental turbulence played a disruptive role in the EU's climate agenda. In the spring, the onset of the Covid-19 pandemic led to a shift of attention away from climate issues and threatened to delay the implementation of the Green Deal. In the autumn, the dispute on rule of law violations in Poland and Hungary became intertwined with EU budget negotiations and caused a dangerous deadlock with con- sequences for many aspects of EU governance, including climate policy. Poland's and Hungary's veto on the EU's budget was also a source of turbulence of scale, as it had an effect at the multilateral level too (both at and beyond the EU level). It delayed the adoption of the 2030 Climate Target Plan and hence the announcement of the EU's nationally determined contribution to the Paris Agreement. Furthermore, the different positions of EU institutions on the 2030 target and several aspects of the 2050 climate framework led to a protracted stall in intra-EU negotiations that was only overcome in May 2021.

On the whole, however, EU governance responses to various types of turbulence have highlighted that climate action remains a priority for the Union. The post-pandemic recovery packages have increased the availability of EU climate finance (see also Dupont et al., 2020, p. 1102). The Commission has reframed the Green Deal as the EU's growth strategy and as an essential part of the economic recovery. At the same time, prospects for the EU's global climate action and for international cooperation improved following the election of Joe Biden to President of the United States in November 2020. The beginning of Biden's presidency, with the return of the US to the Paris climate agreement and the announcement of new US emissions reduction targets, marked a clear departure from the unilateralism and hostility to climate negotiations of his predecessor (Hook \& Politi, 2021). While major challenges to the EU's global climate action persist (cf. Grimm et al., 2021), Biden's election removed an important source of environmental turbulence that had particularly nefarious effects for climate policy. Therefore, while turbulence remains a formidable challenge to EU and global climate action, EU institutions now appear to view the post-pandemic economic restructuring and the changed stance of the US on the climate agenda as opportunities to accelerate the energy transition.

\section{Acknowledgments}

The author would like to thank the editors of this thematic issue and the scholars of the GOVTRAN network for the useful feedback on earlier versions of this article.

\section{Conflict of Interests}

The author declares no conflict of interests.

\section{References}

Agence Europe. (2020a, April 3). Legal opinion of European Parliament services may undermine ambition of climate law, not that of Commission [Press release]. https://agenceurope.eu/en/bulletin/article/12461/ 30

Agence Europe. (2020b, October 24). "Climate Law," partial political agreement of European Environ- 
ment Ministers excluding question of 2030 objective [Press release]. https://agenceurope.eu/en/bulletin/ article/12588/1

Agence Europe. (2020c, October 21). “Climate Law," German EU Council Presidency proposes Member States adopt partial agreement excluding 2030 target issue [Press release]. https://agenceurope.eu/en/bulletin/ article/12585/10

Agence Europe. (2020d, November 18). "Climate Law", green light from Member States' ambassador to start trilogues. https://agenceurope.eu/en/bulletin/ article/12604/15

Agence Europe. (2020e, December 18). EU environment ministers reach a political agreement on entire 'Climate Act'. https://agenceurope.eu/en/bulletin/ article/12625/1

Agence Europe. (2021, February 2). Interinstitutional negotiations on Climate Law are stalled. https:// agenceurope.eu/en/bulletin/article/12649/10

Ansell, C., Sørensen, E., \& Torfing, J. (2020). The Covid-19 pandemic as a game changer for public administration and leadership? The need for robust governance responses to turbulent problems. Public Management Review, 23(7), 949-960.

Ansell, C., \& Trondal, J. (2018). Governing turbulence: An organizational-institutional agenda. Perspectives on Public Management and Governance, 1(1), 43-57.

Ansell, C., Trondal, J., \& Øgård, M. (2016). Turbulent governance. In C. Ansell, J. Trondal, \& M. Øgård (Eds.), Governance in turbulent times (pp. 1-33). Oxford University Press.

Bocse, A. (2020). The UK's decision to leave the European Union (Brexit) and its impact on the EU as a climate change actor. Climate Policy, 20(2), 265-274.

Brooks, E., \& Geyer, R. (2020). The development of EU health policy and the Covid-19 pandemic: Trends and implications. Journal of European Integration, 42(8), 1057-1076.

Collier, D. (2011). Understanding process tracing. PS: Political Science \& Politics, 44(4), 823-830.

Dobbs, M., Gravey, V., \& Petetin, L. (2021). Driving the European Green Deal in turbulent times. Politics and Governance, 9(3), 316-326.

Dupont, C., \& Moore, B. (2019). Brexit and the EU in global climate governance. Politics and Governance, 7(3), 51-61.

Dupont, C., Oberthür, S., \& von Homeyer, I. (2020). The Covid-19 crisis: A critical juncture for EU climate policy development? Journal of European Integration, 42(8), 1095-1110.

European Commission. (2019). The European Green Deal (COM(2019) 640 final).

European Commission. (2020a). Proposal for a regulation of the European Parliament and of the Council establishing the framework for achieving climate neutrality and amending Regulation (EU) 2018/1999 (European Climate Law) (COM(2020) 80 final).

European Commission. (2020b). Europe's moment:
Repair and prepare for the next generation (COM(2020) 456 final).

European Commission. (2020c). Stepping up Europe's 2030 climate ambition. Investing in a climate-neutral future for the benefit of our people (COM(2020) 562 final).

European Commission. (2020d). Amended proposal for a Regulation of the European Parliament and of the Council on establishing the framework for achieving climate neutrality and amending Regulation (EU) 2018/1999 (European Climate Law) (COM(2020) 563 final)

European Council. (2020). European Council meeting (10 and 11 December 2020)-Conclusions.

European Council. (2021). Interinstitutional file (No. 2020/0036). https://data.consilium.europa.eu/ doc/document/ST-8440-2021-INIT/en/pdf

European Parliament. (2020). Non-paper on the choice of delegated acts to set out the trajectory for achieving climate neutrality in the proposal for a European Climate Law (No. 2020/0036(COD)).

Gera, V. (2020, November 16). Poland, Hungary veto EU budget over rule-of-law issue. AP. https://apnews. com/article/budapest-viktor-orban-angela-merkelpoland-coronavirus-pandemic-679affe987f65160e $89 \mathrm{~b} 257884 \mathrm{e} 1 \mathrm{~cd} 2 \mathrm{~b}$

Gora, A., \& de Wilde, P. (2020). The essence of democratic backsliding in the European Union: Deliberation and rule of law. Journal of European Public Policy. Advance online publication. https://doi.org/ 10.1080/13501763.2020.1855465

Greens/EFA. (2019). Greens/EFA Group voted against Ursula von der Leyen [Press release]. https:// www.greens-efa.eu/en/article/press/greens-efagroup-voted-against-ursula-von-der-leyen

Grimm, S., Helwig, N., Mourier, L., Rainers, W., \& Siddi, M. (2021). The global dimension of the European Green Deal: The EU as a green leader? Konrad Adenauer Stiftung. https://www.kas.de/en/web/mnedbruessel/european-green-deal/detail/-/content/ the-global-dimension-of-the-european-green-dealthe-eu-as-a-green-leader

Harvey, F. (2020, December 4). UK vows to outdo other economies with 68 percent emissions cuts by 2030. The Guardian. https://www.theguardian.com/ environment/2020/dec/03/uk-vows-outdo-othermajor-economies-emissions-cuts-by-2030

Heidbreder, E., \& Schade, D. (2020). (Un)settling the precedent: Contrasting institutionalisation dynamics in the Spitzenkandidaten procedure of 2014 and 2019. Research and Politics, 7(2), 1-6. http://doi.org/ $10.1177 / 2053168020925975$

Hook, L., \& Politi, J. (2021, April 22). US to propose emissions cut of at least 50 percent by end of decade. Financial Times. https://www.ft.com/ content/32f5e2cd-4689-4434-9da0-d97d46673eaf

Khan, M., \& Brunsden, J. (2020, April 3). Dumping Europe's green ideals. Financial Times. https://www. 
ft.com/content/2c44c927-f007-4fbd-8b20-4d467c $45 \mathrm{a} 0 \mathrm{c} 2$

Knops, L. (2021). Stuck between the modern and the terrestrial: The indignation of the youth for climate movement. Political Research Exchange, 3(1), Article e1868946. Advance online publication. https:// doi.org/10.1080/2474736X.2020.1868946

Lindberg, M. B. (2019). The EU emissions trading system and renewable energy policies: Friends or foes in the European Policy Mix? Politics and Governance, $7(1)$, 105-123.

Loss, R. (2020, December 17). Warming relations: UK-EU climate cooperation after Brexit. European Council on Foreign Relations. https://ecfr.eu/article/ warming-relations-uk-eu-climate-cooperation-afterbrexit

Makszimov, V. (2020, November 5). EU institutions strike budget deal on rule of law mechanism. Euractiv. https://www.euractiv.com/section/all/news/euinstitutions-strike-deal-on-rule-of-law-mechanism

Mudde, C. (2019). The 2019 EU elections: Moving the center. Journal of Democracy, 30(4), 20-34.

Oberthür, S. (2019). Hard or soft governance? The EU's climate and energy policy framework for 2030. Politics and Governance, 7(1), 17-27.

Parker, C. F., Karlsson, C., \& Hjerpe, M. (2017). Assessing the European Union's global climate change leader- ship: From Copenhagen to the Paris Agreement. Journal of European Integration, 39(2), 239-252.

Siddi, M. (2016). The EU's energy union: A Sustainable Path to Energy Security? The International Spectator, 51(1), 131-144.

Siddi, M. (2020). The European Green Deal: Assessing its current state and future implementation (Working Paper No. 114). FIIA.

Simon, F. (2020, April 16). Full list of delayed European Green Deal initiatives. Euractiv. https://www. euractiv.com/section/energy-environment/news/ leaked-full-list-of-delayed-european-green-dealinitiatives

Valero, J. (2020, December 11). EU leaders unlock historic $€ 1.8$ trillion budget deal. Euractiv. https:// www.euractiv.com/section/economy-jobs/news/euleaders-unlock-historic-e1-8-trillion-budget-deal

Vihma, A., Reischl, G., Andersen, A. N., \& Berglund, S. (2020). Climate change and populism (Report No. 64). FIIA.

Von der Leyen, U. (2019). A Union that strives for more. My agenda for Europe. European Commission.

von Homeyer, I., Oberthür, S., \& Jordan, A. J. (2021). EU climate and energy governance in times of crisis: Towards a new agenda. Journal of European Public Policy. Advance online publication. https://doi.org/ 10.1080/13501763.2021.1918221

\section{About the Author}

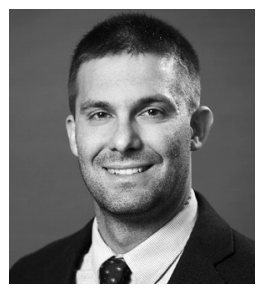

Marco Siddi is senior research fellow at the Finnish Institute of International Affairs (FIIA) and Montalcini assistant professor at the University of Cagliari, Italy. He has been coordinator of the project "The Politics of Climate Change" at FIIA and a researcher in the Horizon 2020 project "EUIDEAIntegration and Differentiation for Effectiveness and Accountability." 